\title{
Waste of leaf-cutting ants: disposal, nest structure, and abiotic soil factors around internal waste chambers
}

\author{
Sandra S. Verza ${ }^{1} \cdot$ Eduardo A. Diniz $^{2} \cdot$ Mara F. Chiarelli $^{1}$. \\ Rosilda M. Mussury ${ }^{3}$. Odair C. Bueno ${ }^{1}$
}

Received: 1 February 2016/Revised: 25 January 2017 / Accepted: 6 February 2017 /Published online: 15 February 2017

(C) Springer-Verlag Berlin Heidelberg and ISPA 2017

\begin{abstract}
Leaf-cutting ants produce large quantities of waste that harbor bacteria and fungi that are harmful to the colony. To be protected from these pathogens, the workers of Atta species present a sophisticated organization to manage harmful material, which can be deposited outside the nest or in internal chambers. However, little is known about the behavior of Acromyrmex species in handling and disposal of waste. Due to some observations, we assume that the same species of Acromyrmex can deposit waste outside the nest and into internal chambers and raise the following question: what determines the occurrence of internal waste chambers in Acromyrmex? To address this question, we verified whether nest depth influences the waste-chamber occurrence. We also verified the nest structure and the abiotic factors of soil beside each waste-chamber: $\mathrm{pH}$ and water content of the soil. For this, eight nests were excavated for Acromyrmex balzani and Acromyrmex rugosus rugosus. We verified that not only can the same leaf-cutting ant species deposit debris both outside and inside the nest but also the same nest can present internal chambers and external waste deposit. The soil beside the waste chamber always presented an acidic $\mathrm{pH}$, while the humidity varied widely. Our results showed that the nest depth was highly correlated with the depth of the waste chamber
\end{abstract}

Sandra S. Verza

sandraverza@yahoo.com

1 Centro de Estudo de Insetos Sociais, Universidade Estadual Paulista, UNESP, Av. 24-A, n. 1515, Bela Vista, Rio Claro, SP 13506-900, Brazil

2 Gabinete da Presidência, Conselho Nacional de Desenvolvimento Científico e Tecnológico, CNPq, Brasília, DF, Brazil

3 Faculdade de Ciências Biológicas e Ambientais, Universidade Federal da Grande Dourados, UFGD, Dourados, MS, Brazil $(p=0.0003)$ and probably has some influence on waste disposal. The characteristics of the nest and the role of depth in the choice of waste chamber location are discussed.

Keywords Acromyrmex - Debris chambers · Garbage disposal $\cdot$ Nest depth $\cdot$ Waste management

\section{Introduction}

Leaf-cutting ants cultivate and utilize as food a symbiotic fungus rich in nutrients, but that may contain microorganisms extremely aggressive to the colony (Bot et al. 2001; Hart and Ratnieks 2002), as the fungus Escovopsis (Ascomycota), a fungus garden mycoparasite that is capable of causing the death of the colony (Currie et al. 1999; Reynolds and Currie 2004). When depleted in nutrients, the workers remove portions of old fungus, together with dead workers, and handle them in a special manner (Hart and Ratnieks 2002; Hughes et al. 2004).

In the genus Atta, for example, the majority of species deposit such debris in special cavities inside the nest, except for Atta colombica and Atta mexicana, which deposit waste externally (Haines 1978; Deloya 1988; Hart and Ratnieks 2002). In Acromyrmex, little is known about waste deposition; until recently, it was thought that all the species deposited waste externally (Gonçalves 1961). But Verza et al. (2007), during excavations of nests of Acromyrmex rugosus rugosus (dicot cutters), found in the majority of them internal chambers with waste, being the first confirmed report for this genus. The authors also observed that the fungus chambers were located closer to the surface, while the waste chambers were the deepest. Occasionally, Verza (personal obs. 2008) also observed external waste in nests of this same species. 
Another interesting occurrence was observed in Acromyrmex landolti and Acromyrmex balzani (grass cutters) in which the authors Lapointe et al. (1998) and Caldato (2010), respectively, found in some nests, chambers filled with a substrate of depleted leaves. However, these authors did not give importance to the fact, since the workers of this species normally carry excavated soil and waste outside of the nest.

Many Acromyrmex species dispose of their waste externally including A. balzani, A. fracticornis, A. landolti, A. hispidus, A. coronatus, A. lobicornis, A. lundi pubences, A. striatus, and A. subterraneus (Gonçalves 1961; Fowler 1979; Della Lucia and Moreira 1993). There are some species of this genus that construct an external mound of soil, often interspersed with plant material but not necessarily what might be called waste (Gonçalves 1961; Forti et al. 2006).

It is known that the majority of leaf-cutting ants build underground nests, edified by removal of a large quantity of soil to the surface but with very different structural characteristics. Thus, while some leaf-cutting species construct underground chambers for depositing their debris, others dispose of their debris outside of the nest, in a single deposit of waste or in a few locations on the soil at a safe distance from the nest. The principal function of these nests, as well as those of other social insects is to protect the colony from natural enemies and other dangers as pathogenic microorganisms present in the waste and fungus, in addition to favoring the microclimatic conditions appropriate for their maintenance (Sudd 1982). Humidity is critical to the growth of the mutualist fungus (Roces and Kleineidam 2000). The fungus can incur severe damage at humidity levels below $60 \%$ and temperatures above $33{ }^{\circ} \mathrm{C}$ (Powell and Stradling 1986). However, the internal humidity of the nest can be regulated by the ants that open and close the entrance holes of the nests, according to the microclimatic necessities, which are required for the maintenance of the fungus garden (Bolazzi and Roces 2010).

The stress caused by unsuitable conditions of temperature, $\mathrm{pH}$, and humidity can lead to situations of imbalance in the symbiotic fungus, with an increase in harmful microorganisms and a greater deleterious impact related to waste. According to Ribeiro and Navas (2007), the growth of undesirable microorganisms in the waste would increase with humidity, and therefore, drier areas would be more suitable for the disposal of waste on the ant Atta sexdens rubropilosa.

On the other hand, microorganisms are sensitive to their chemical environments. Much attention has been paid to the soil reaction and associated factors. The acid $\mathrm{pH}$ is common in all regions where precipitation is high enough to leach appreciable amounts of exchangeable bases (such as calcium and magnesium) into the drainage water (Brady 1989). The acidic environment makes it unfavorable environment for soil microbial life (Silva 1997). Thus, our hypothesis would be that the waste chambers are constructed in places with the acidic and more humid soil to control the proliferation of microorganisms.
The genus Acromyrmex presents a great diversity of nest types, with characteristics specific to each species. Ranging from the less elaborate like those of A. crassispinus, which are on the surface (epigeus) with a single large chamber situated in a shallow excavation, covered with straw and vegetable residues, up to the most complex such as arboreal ones from A. coronatus, made from sticks and small leaves, or underground ones from A. rugosus and A. balzani. The underground nests may reach a depth of $5 \mathrm{~m}$, but the majority are shallower, achieving a maximum depth of $1 \mathrm{~m}$, and may be covered with soil or, at times, be inconspicuous. Generally, they present one or a few chambers, with 26 being the maximum number of chambers ever reported for a nest of this genus (Gonçalves 1961; Navarro and Jaffe 1985; Della Lucia and Moreira 1993; Verza et al. 2007).

In addition to these differences, for reasons still unknown, within the same species, the nests present variations in depth, diameter, and format of chambers and tunnels. Lapointe et al. (1998) found in A. landolti, that the nests were deeper during the dry season than in the rainy season, probably in order to achieve adequate conditions for the survival of the colony. It is worth emphasizing at this point that the nests of this species (they range from $5 \mathrm{~cm}$ to $5 \mathrm{~m}$ in depth) and those of A. rugosus rugosus (from $6 \mathrm{~cm}$ to almost $4 \mathrm{~m}$ ), together with those of A. rugosus rochai (that reach up to $4 \mathrm{~m}$ ), are the deepest among Acromyrmex species (Gonçalves 1961; Navarro and Jaffe 1985; Verza et al. 2007). As can be noted, they vary highly in depth, and Verza et al. (2007) suggest that deeper nests may be constructed to utilize a soil humidity gradient that is better for the cultivation of the fungus.

Based on the above information, the present study aimed to verify: (i) the nest structure and whether the depth of the nest influences the occurrence of waste chamber; (ii) the humidity and $\mathrm{pH}$ at the waste-chamber location; and (iii) if the same ant species can deposit debris outside the nest and in internal chambers.

\section{Materials and methods}

\section{Excavation and characterization of nests}

The excavations of nests were carried out in the state of São Paulo, in the municipalities of Corumbataí $\left(22^{\circ} 13^{\prime} 13.5^{\prime \prime} \mathrm{S}\right.$, $\left.47^{\circ} 37^{\prime} 31.9^{\prime \prime} \mathrm{W}\right)$, Itirapina ( $22^{\circ} 15^{\prime} 35.8^{\prime \prime} \mathrm{S}, 47^{\circ} 52^{\prime} 44.5^{\prime \prime} \mathrm{W}$ ), and Rio Claro $\left(22^{\circ} 23^{\prime} 50.8^{\prime \prime} \mathrm{S}, 47^{\circ} 32^{\prime} 51.9^{\prime \prime} \mathrm{W}\right)$. Four nests were excavated with different area dimensions of loose soil, for each of the following species: A. balzani (grass cutters) and A. rugosus rugosus (dicot cutters).

Prior to initiating the excavation, the entrance holes around the nests were detected using a neutral talcum powder with a manual pump, which was introduced in one of the entrances. The areas around the nests were also inspected for the 
presence of waste deposits, for which the workers, upon exiting from the different nest holes, were followed to the point at which they stopped. When the deposits were found, their distance was measured in relation to the exit location of the nest workers.

After selecting the nest, the excavation process was initiated by opening a small ditch around the nest coverage area, excavating from the outside to the inside and deepening according to the appearance of chambers, with attention directed toward the tunnels, aiming to not lose any chamber, whose quantity and measurements were recorded. The length of the tunnels and the depth of chambers in relation to the soil surface were measured.

\section{Measurement of soil water content and pH}

To measure the $\mathrm{pH}$ and water content of the soil where a waste chamber was found, soil samples were collected from excavations beside each waste chamber. The soil content was removed by introducing $15 \mathrm{~mL}$ pots into the soil, which were completely filled and capped, and then placed in plastic bags to minimize the humidity losses and taken to the laboratory, with only one sample being collected for each waste chamber. To calculate the percentage of water content, the samples were standardized $(5 \mathrm{~g})$, weighed on an analytic balance, and then placed on a humidity-determining balance at $150{ }^{\circ} \mathrm{C}$ and dried for $30 \mathrm{~min}$ on average. The $\mathrm{pH}$ of this soil was determined by a pH meter utilizing $5 \mathrm{~g}$ of soil for $30 \mathrm{~mL}$ of distilled water.

\section{Statistical analysis}

For the description of nest measurements, the mean and standard deviation were calculated. Spearman's correlation tests were used to verify correlations between maximum depth (m) of the nest with the waste chambers, entrance holes, and external area of the nest, as well as to study associations between data on waste chamber depth, humidity, and $\mathrm{pH}$. KruskalWallis tests were used for interspecific comparisons of the number of entrance holes and the size of the external area between species studied.

\section{Results}

\section{Description of nests}

In A. balzani, all the studied nests presented external waste, although in the cold dry period of the year in a small quantity, varying from 1 to $3 \mathrm{~g}$, approximately (Fig. 1a, b). Waste chambers were found in almost all excavated nests, an occurrence that had not yet been recorded in A. balzani, only one nest did not present waste chambers. On the other hand, in the majority of nests, empty chambers were also found, as shown in
Figs. $1 \mathrm{c}$ and 2 . These empty cavities were probably available to receive fungus or waste, but in one of the nests perhaps had been utilized to accommodate fungus culture since it was located above a fungus chamber currently in use. No nest of this species possessed chambers of soil, but in waste chambers, in addition to depleted vegetable material and dead ants, there was also much soil (Fig. 1d). This could account for the absence or paltry external accumulation of excavated soil.

All the excavated nests of A. rugosus rugosus presented waste chambers (Figs. 2 and 3). About 6 months before its excavation, the first nest presented an accumulation of external waste, which was located $30 \mathrm{~cm}$ from the feeding orifice (entrance hole, with tunnel connected to fungus chamber), with an individual tunnel (through which, the waste is removed to the outside of the nest) for waste removal on its side, as shown in Fig. 3a. However, at the time of the nest excavation, there was no external deposit of debris, and two waste chambers were found on the opposite side of the place where previously was the external waste. One of the waste chambers was at a diagonal distance of $20 \mathrm{~cm}$ above from a fungus chamber, and the tunnel was found blocked with excavated soil. The other one was active, with Coleoptera and depleted fungus located beside a fungus chamber, reaching a depth of $40 \mathrm{~cm}$.

The second A. rugosus rugosus nest excavated was similar to the first, with an individual external tunnel for waste removal, but without any sign of an external waste deposit, and following this tunnel, about $40 \mathrm{~cm}$ deep was found a cavity with waste, which was interconnected by an internal tunnel to the fungus garden, with the chambers being about $90 \mathrm{~cm}$ apart. On the other hand, in the other nests were found both external waste deposits (Fig. 3b) and internal waste chambers with the presence of many larvae of Elateridae (Coleoptera), which is a characteristic of this ant species (Fig. 3c). One nest had an external waste deposit on the mound of loose soil (Fig. 3d).

The number of entrance holes $(\mathrm{H}=0.10, p=0.7518)$ and the external area size $(H=1.08, p=0.2975)$ did not differ statistically between the species. The number of entrance holes of the Acromyrmex nests studied varied from 1 to 3 . The external area of the nest varied between 0.04 and $0.28 \mathrm{~m}^{2}$ (Table 1).

\section{Depth of nests}

The depth of A. balzani nests (deepest chamber) ranged from $15 \mathrm{~cm}$ to almost $1 \mathrm{~m}$. While in A. rugosus rugosus, it varied from 40 to $70 \mathrm{~cm}$ (Table 1). But it is worth noting here that the nests of the latter species can reach a depth of almost $4 \mathrm{~m}$ (Verza et al. 2007).

The total number of nest chambers varied from 2 to 5 (Table 1), which showed irregular shapes and with different dimensions. The depth of nests did not present correlation 
Fig. 1 Acromyrmex balzani nest. a Detail of entrance hole. $\mathbf{b}$ General view, where the white arrows indicate the entrance hole and the black arrow indicate soil mound with waste. c Empty chamber. d Waste chamber

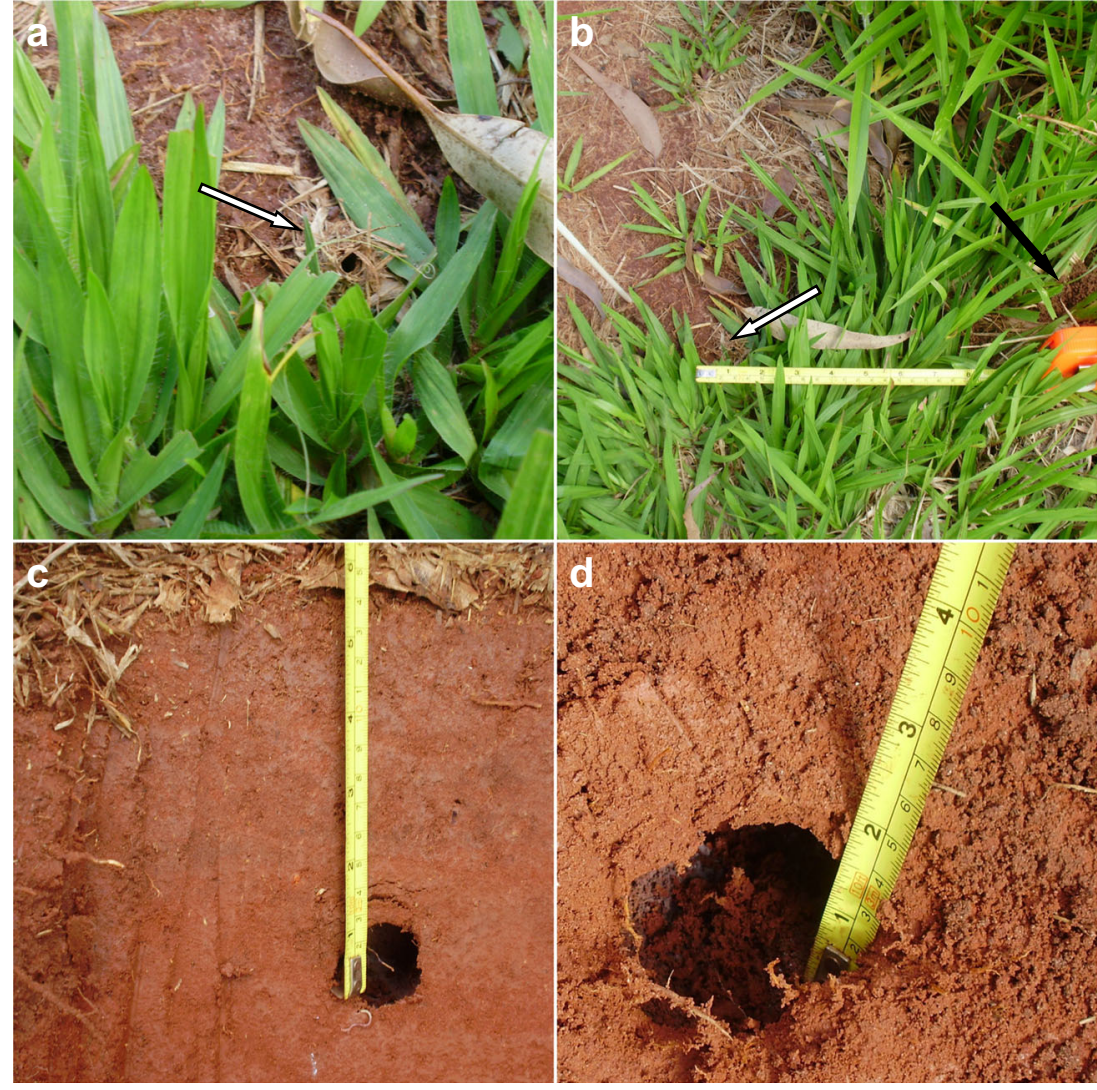

with the length of the chambers $(r s=0.67, p=0.070)$, nor with width $(r s=0.63, p=0.096)$ or height $(r s=0.70$, $p=0.065$ ).

Waste chambers were found only in nests with depths of $20 \mathrm{~cm}$ or higher, one of these chambers reached $95 \mathrm{~cm}$; however, a waste chamber was located $13 \mathrm{~cm}$ deep in nest b2 (nest with a total depth of $20 \mathrm{~cm}$ ). Nevertheless, it was observed that the mean depth of waste chambers in the nests of both species studied was $40.60 \mathrm{~cm}(\mathrm{SD}=24.86)$.

We verified that the nest depth was highly correlated with the depth of the waste chamber $(r s=0.90, p=0.0003)$ but not

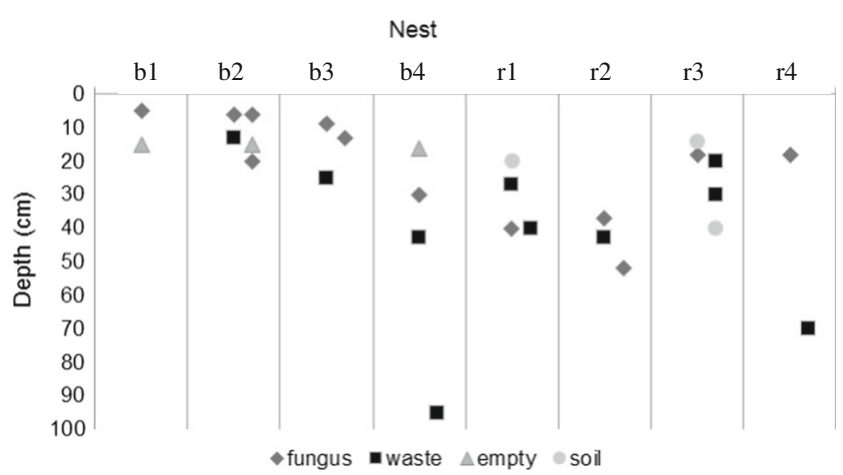

Fig. 2 Depth of chambers found in eight Acromyrmex nests. The chambers are differentiated according to their content. Nests b1 to b4: Acromyrmex balzani and r1 to r4: Acromyrmex rugosus rugosus correlated with the number of waste chambers $(r s=0.55$, $p=0.157)$.

The depth of nests also did not correlate with the number of entrance holes $(r s=-0.17, p=0.674)$ nor with the external nest area $(r s=-0.01, p=0.965)$.

\section{Characterization of soil in the nests}

The soil humidity at the waste-chamber location in Acromyrmex nests varied between 5.95 and $22.98 \%$. The soil samples presented an acidic $\mathrm{pH}$, averaging 5.0 (Table 2). However, waste chamber depth was not significantly correlated with soil humidity $(r s=0.22, p=0.5410)$ nor with soil $\mathrm{pH}$ $(r s=-0.19, p=0.6064)$.

Although some nests of both species presented a higher humidity in the soil beside the deeper waste chambers and a more acidic soil $\mathrm{pH}$ beside the shallower waste chambers (Table 2), the values were highly similar among the waste chambers of each of these nests.

\section{Discussion}

Our results showed that the same species of leaf-cutting ant can deposit waste both inside and outside of the nest. Currently, in only one species of the genus Acromyrmex 
Fig. 3 Acromyrmex rugosus rugosus nest. a Overview nest outside area, the black arrow indicates the waste in the pile of soil, next is an individual tunnel hole for waste removal (yellow arrow), located $30 \mathrm{~cm}$ from the entrance holes indicated by white arrow. b, d General view of the soil mound and external waste. b Waste next to the mound and $\mathbf{d}$ waste on the mound. Mounds with entrance hole are indicated by white arrows, and the black arrows indicate the external waste. c Waste chamber in detail with red arrow indicating the presence of larvae of Elateridae (Coleoptera)

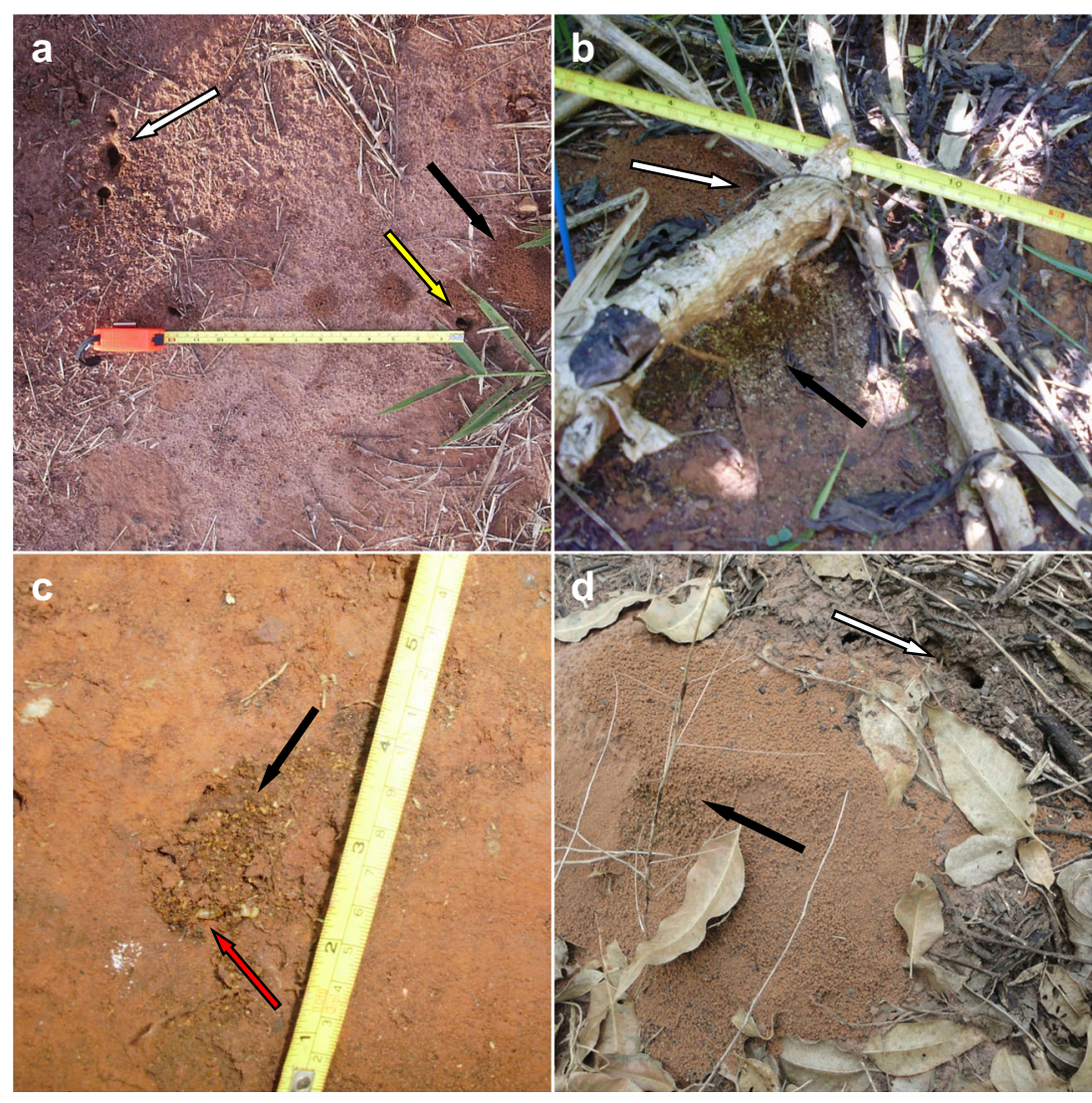

(A. rugosus rugosus) has been recorded the occurrence of internal chambers with waste (Verza et al. 2007). Nevertheless, during the development of this work, waste chambers were also found in A. balzani, making it the second occurrence of these chambers confirmed in Acromyrmex. It is worth remembering here that $A$. balzani was described in literature as an external waste depositor (Gonçalves 1961; Silva et al. 2011). On the other hand, in the present study, A. rugosus rugosus presented external waste deposit, something not observed in the nests utilized by Verza et al. (2007) and not yet reported in literature by other researchers.

Another unprecedented fact was the occurrence of external deposits and internal waste chambers in the same nest, that is, at the same time, in both species of Acromyrmex. Based on our results, it seems probable that the nest depth plays an important role in the occurrence of internal waste chambers by workers of this genus, for although some shallow nests have waste chambers, most of the nests that presented such cavities

Table 1 Number and dimensions (mean and SD) of chambers, external area, number of entrance, and depth of Acromyrmex nests. Nests b1 to b4: Acromyrmex balzani and r1 to r4: Acromyrmex rugosus rugosus

\begin{tabular}{|c|c|c|c|c|c|c|c|c|}
\hline Nest & Chambers $(n)$ & $\begin{array}{l}\text { Waste } \\
\text { chambers }(n)\end{array}$ & $\begin{array}{l}\text { Chamber } \\
\text { length }(\mathrm{cm}) \\
\text { Mean } \pm \text { SD }\end{array}$ & $\begin{array}{l}\text { Chamber } \\
\text { width }(\mathrm{cm}) \\
\text { Mean } \pm \text { SD }\end{array}$ & $\begin{array}{l}\text { Chamber } \\
\text { height }(\mathrm{cm}) \\
\text { Mean } \pm \text { SD }\end{array}$ & Nest area $\left(\mathrm{m}^{2}\right)$ & $\begin{array}{l}\text { Entrance } \\
\text { holes }(n)\end{array}$ & Nest depth $(\mathrm{cm})$ \\
\hline b1 & 2 & - & $6.0 \pm 1.4$ & $4.5 \pm 2.1$ & $3.8 \pm 1.8$ & 0.05 & 1 & 15 \\
\hline b2 & 5 & 1 & $4.6 \pm 1.5$ & $3.9 \pm 0.7$ & $4.3 \pm 1.1$ & 0.08 & 3 & 20 \\
\hline b3 & 3 & 1 & $7.3 \pm 2.5$ & $4.3 \pm 1.5$ & $6.0 \pm 2.0$ & 0.28 & 3 & 25 \\
\hline b4 & 4 & 2 & $9.8 \pm 3.6$ & $6.5 \pm 1.0$ & $9.5 \pm 3.9$ & 0.04 & 1 & 95 \\
\hline r1 & 4 & 2 & $17.3 \pm 8.4$ & $9.8 \pm 4.1$ & $14.5 \pm 7.6$ & 0.28 & 1 & 40 \\
\hline $\mathrm{r} 2$ & 3 & 1 & $14.0 \pm 5.3$ & $13.0 \pm 3.6$ & $11.7 \pm 2.3$ & 0.26 & 1 & 52 \\
\hline r3 & 5 & 2 & $12.3 \pm 4.1$ & $7.0 \pm 1.6$ & $9.0 \pm 3.0$ & 0.05 & 2 & 40 \\
\hline r4 & 2 & 1 & $17.5 \pm 2.1$ & $8.0 \pm 2.8$ & $11.5 \pm 4.9$ & 0.28 & 3 & 70 \\
\hline
\end{tabular}


Table 2 Depth of each waste chamber and percentage of water content and $\mathrm{pH}$ of soil beside each chamber. Nests $\mathrm{b} 2$ to b4: Acromyrmex balzani and $\mathrm{r} 1$ to $\mathrm{r} 4$ : Acromyrmex rugosus rugosus

\begin{tabular}{llll}
\hline Nests & $\begin{array}{l}\text { Depth of waste } \\
\text { chamber }(\mathrm{cm})\end{array}$ & Soil humidity $(\%)$ & Soil pH \\
\hline b2 & 13 & 15.71 & 5.5 \\
b3 & 25 & 15.96 & 2.8 \\
b4 & 43 & 21.84 & 4.8 \\
b4 & 95 & 22.98 & 5.6 \\
r1 & 27 & 8.35 & 6.0 \\
r1 & 40 & 8.28 & 6.2 \\
r2 & 43 & 21.15 & 3.2 \\
r3 & 20 & 11.06 & 5.9 \\
r3 & 30 & 12.63 & 5.1 \\
r4 & 70 & 5.95 & 4.0 \\
\hline
\end{tabular}

of internal residues were deep. Thus, it is believed that the depth of the waste chamber, as well as that of the nest, may vary due to several factors such as the age of the colony, type of soil, and other microclimatic conditions, being limited by the water table (Jonkman 1980; Moreira et al. 2004, Van Gils and Vanderwoude 2012).

It is known that some Acromyrmex species can dig deeper nests, when founded in locations with a higher soil temperature, and that, depending on the regime of temperature and of sun exposure of the nests, they present superficial or underground foundations, being that such variations may occur even within the same species (Bolazzi et al. 2008). The same authors observed that $A$. lundi workers use soil temperature as a guidance cue to decide where to commence digging, and that they respond to the oscillations of soil temperature, shifting to alternative excavation sites, or stopping the excavation. The preferred soil temperature range for nest construction is between 20 and $30.6{ }^{\circ} \mathrm{C}$, corresponding to the scale at which colony growth would be maximized.

Some of the nests of both species presented a more acidic $\mathrm{pH}$ in the soil beside the shallower waste chambers and a higher humidity in the soil beside the deeper chambers. It was expected that the deeper waste chambers would be constructed in places with the acidic and more humid soil to control the proliferation of microorganisms. However, the waste chamber depth was not significantly correlated with soil humidity and soil $\mathrm{pH}$. The soil beside the waste chamber, in the present work, always presented an acidic $\mathrm{pH}$, while that the humidity varied presenting a mean of $14 \%$.

Studies related to abiotic factors of soil in nests of leafcutting ants are scarce in the literature. One recent study showed that the humidity content of nest soil in A. colombica varies between 30 and $52 \%$, while the $\mathrm{pH}$ of the soil above the fungus chambers averaged 5.7 (Hudson et al. 2009). Ribeiro and Navas (2007) found that 30 of 30 sub-colonies of Atta sexdens rubropilosa tested for hygropreference chose dry chambers for waste disposal when offered a choice between dry and wet chambers; however, it is worth remembering that it was an experiment carried out under controlled laboratory conditions.

According to Farji-Brener et al. (2016), the construction of underground chambers for disposal of waste is considered a more derivative form of behavior, while the external disposal of waste is the ancestral condition. However, despite the influence of phylogeny, environmental conditions also regulate the final destination of the waste. In xeric habitats, almost all species of leaf-cutting ants present waste externally, whereas in pastures and subtropical and tropical forests are dominated by species with internal chambers. Thus, the dry and hot conditions of xeric habitats allow the ants to locate their residues externally with minimal risk of infection.

In the present work, it was observed that A. balzani deposited a lesser quantity of waste in the cold dry period of the year, probably because in this season, the colony reduces its activities to save energy, as a function of food scarcity in this period, that is, the ants try to conserve energy by reducing the number of trips to the surface.

According to Roces and Hölldobler (1994), the fungus chambers may be located closer to the surface to save energy and time to workers during transportation of substrates to the fungus chambers. As this may be considerable, probably the external disposition of waste in Acromyrmex eliminates the energy expenditure on excavation of chambers. On the other hand, internal chambers can provide for the workers greater economy of work, due to the exclusion of long trips to the soil surface.

As for the connections of the waste chambers to fungus chambers, according to observations, one of the tunnel of A. rugosus rugosus was blocked with excavated soil by these workers, similar to Verza et al. (2007), whereas the active waste chambers are always found connected to the fungus chambers through tunnels. Ants are subject to the action of deterrent substances produced by organisms that invade their nests. Normally, these organisms are found in the waste chambers, such as the specialized parasitic fungus Escovopsis (Bot et al. 2001; Hart and Ratnieks 2001) which implies the necessity for workers to develop mechanisms to protect their nest and symbiotic fungus garden. Thus, the blockage of access tunnels to inactive waste chambers may be a behavioral strategy adopted by the species studied as a means of diminishing the potential for contaminating the colony.

The external disposition of waste in Acromyrmex probably also serve to diminishing the risks of diseases in the colony. Some studies even show that the workers that handle residues are prevented from reentering the main nest (Hart and Ratnieks 2001; Ballari et al. 2007); on the other hand, in Acromyrmex echinatior, the workers contaminated with waste are treated aggressively by their nest-mates. But surprisingly, 
when the residues are removed from their bodies, most of them return to taking care of the fungus garden or to their original work (Waddington and Hughes 2010).

Other protection strategies are also adopted by the colony. For example, in A. lobicornis, the waste is deposited outside of the nest, and Farji-Brener and Sasal (2003) suggest that the external environmental conditions may influence the loss of dangerous effects of these microorganisms. More recently, the researchers Farji-Brener and Tadey (2012) documented that these ants "recycle" waste materials to repair damage to the nest mound, but this occurs only during the hottest season of the year. Thus, these reports could perhaps explain the presence of a waste deposit on the mound of loose soil in one of the nests of A. rugosus rugosus studied in the present work.

Furthermore, A. rugosus rugosus build nests generally near tree, and according to Hudson et al. (2009), the waste mounds provide high concentrations of nutrients that can be exploited by nearby plants. Haines (1978) reported that the waste outside active nests of $A$. colombica sampled in the dry season (presumably less leached) was considerably enriched in relation to a series of elements, including nitrogen, sulfur, potassium, and phosphorus. Additionally, Hudson et al. (2009) verified in this same species that the waste from active nests contained a higher concentration of total nutrients than the soil around the nest, but these concentrations were diminished in recently abandoned nests. But, the soil under the waste material contained high concentrations of ammonium nitrate that persisted after the disappearance of the waste. Already in Atta sexdens, a species that forms waste chambers, deep soils $(>1 \mathrm{~m})$ around nests, contain more elevated concentrations of cations, inorganic nitrogen, and organic material than the surrounding soil (Moutinho et al. 2003; Verchot et al. 2003).

However, A. rugosus rugosus is evidently opportunistic when building nests and taking advantage of the immediate environment. In Verza et al. (2007), this was most obvious, when old roots of trees were utilized as guidelines for tunnels, most probably to reinforce the structure of the nest. Thus, in addition to each species presenting species-specific behavior (Specht et al. 1994), it may be stated that each colony can present its own necessities related to the environment in which it lives.

In this manner, we conclude that the soil next to the waste chamber is always acidic and humid, regardless of depth. Moreover, we can deduce that the external disposition of waste in Acromyrmex, in addition to diminishing the risks of diseases in the colony, eliminates the energy expenditure on excavation of chambers. On the other hand, internal chambers are costly to dig but can provide for the workers lesser exposure to predators and greater economy of work, due to the exclusion of long trips to and from the soil surface. Thus, the construction of waste chambers in nests may be attributed to an adaptive specialization to save time and energy.
Acknowledgments We wish to thank the São Paulo Research Foundation (FAPESP) and the National Council for Scientific and Technological Development (CNPq) for the fellowship granted to the first author (grant 2008/00522-9, FAPESP) and for the financial support (grant 2006/58043-3, FAPESP; grant 163911/2013-4, CNPq). We would like to thank Amanda Carlos and José Macena for the assistance with data collection. We also appreciate the reviewer's valuable suggestions.

\section{References}

Ballari S, Farji-Brener AG, Tadey M (2007) Waste management in the leaf-cutting ant Acromyrmex lobicornis: division of labour, aggressive behaviour, and location of external refuse dumps. J Insect Behav 20:87-98

Bollazzi M, Kronenbitter J, Roces F (2008) Soil temperature, digging behaviour, and the adaptive value of nest depth in South American species of Acromyrmex leaf-cutting ants. Oecologia 158:165-175

Bollazzi M, Roces F (2010) Leaf-cutting ant workers (Acromyrmex heyeri) trade off nest thermoregulation for humidity control. J Ethol 28:399-403

Bot ANM, Currie CR, Hart AG, Boomsma JJ (2001) Waste management in leaf-cutting ants. Ethol Ecol Evol 13:225-237

Brady NC (1989) Natureza e propriedades dos solos. 7. ed. Rio de Janeiro: Freitas Bastos. p 898 .

Caldato N (2010) Biologia de Acromyrmex balzani Emery, 1890 (Hymenoptera, Formicidae). Dissertation, São Paulo State University

Currie CR, Mueller UG, Malloch D (1999) The agricultural pathology of ant fungus gardens. P Natl Acad Sci USA 96:7998-8002

Della Lucia TMC, Moreira DDO (1993) Caracterização dos Ninhos. In: Della Lucia TMC (ed) As Formigas Cortadeiras. Folha de Viçosa, Viçosa, Brasil, pp 32-42

Deloya C (1988) Coleópteros lamelicornios asociados a depósitos de detritos de Atta mexicana (Smith) (Hymenoptera: Formicidae) em el sur del Estado de Morelos, México. Folia Entomol Mex 75:77-91

Farji-Brener AG, Sasal Y (2003) Is dump material an effective smallscale deterrent to herbivory by leaf-cutting ants? Écoscience 10: $151-154$

Farji-Brener AG, Tadey M (2012) Trash to treasure: leaf-cutting ants repair nest-mound damage by recycling refuse dump materials. Behav Ecol 23:1195-1202

Farji-Brener AG, Elizalde L, Fernández-Marín H, Amador-Vargas S (2016) Social life and sanitary risks: evolutionary and current ecological conditions determine waste management in leaf-cutting ants. Proc R Soc B 283:1-7

Forti LC, Andrade ML, Andrade APP, Juliane FSL, Ramos VM (2006) Bionomics and identification of Acromyrmex (Hymenoptera: Formicidade) through an illustrated key. Sociobiology 48:135-153

Fowler HG (1979) Las hormigas cortadoras del Paraguay de los géneros Atta Fabricius y Acromyrmex Mayr: bionomia, distribución y sistemática. Inform Cient 2:30-70

Gonçalves CR (1961) O gênero Acromyrmex no Brasil (Hymenoptera, Formicidae). Stud Entomol 4:113-180

Haines B (1978) Element and energy flows through colonies of the leafcutting ants Atta colombica in Panama. Biotropica 10:270-277

Hart AG, Ratnieks FLW (2001) Task partitioning, division of labour and nest compartmentalisation collectively isolate hazardous waste in the leaf-cutting ant Atta cephalotes. Behav Ecol Sociobiol 49:387392

Hart AG, Ratnieks FLW (2002) Waste management in the leaf-cutting ant Atta colombica. Behav Ecol 13:224-231

Hudson TM, Turner BL, Herz H, Robinson JS (2009) Temporal patterns of nutrient availability around nests of leaf-cutting ants (Atta 
colombica) in secondary moist tropical forest. Soil Biol Biochem 41:1088-1093

Hughes WHO, Thomsen L, Eilenberg J, Boomsma JJ (2004) Diversity of entomopathogenic fungi near leaf-cutting ant nests in a neotropical forest, with particular reference to Metarhizium anisopliae var. anisopliae. J Invertebr Pathol 85:46-53

Jonkman JCM (1980) The external and internal structure and growth of nests of the leaf-cutting ant Atta vollenweideri Forel, 1893 (Hym: Formicidae) part I. Z Angew Entomol 89:158-173

Lapointe SL, Serrano MS, Jones PG (1998) Microgeographic and vertical distribution of Acromyrmex landolti (Hymenoptera: Formicidae) nests in a neotropical savanna. Environ Entomol 27:636-641

Moreira AA, Forti LC, Andrade APP, Boaretto MAC, Lopes JFS (2004) Nest architecture of Atta laevigata (F. Smith, 1858) (Hymenoptera: Formicidae). Stud Neotrop Fauna Environ 39:109-116

Moutinho P, Nepstad DC, Davidson EA (2003) Influence of leaf-cutting ant nests on secondary forest growth and soil properties in Amazonia. Ecology 84:1265-1276

Navarro JG, Jaffe K (1985) On the adaptive value of nest features in the grass-cutting ant Acromyrmex landolti. Biotropica 17:347-348

Powell R, Stradling D (1986) Factors influencing the growth of Attamycetes bromatificus, a symbiont of Attine ants. Trans $\mathrm{Br}$ Mycol Soc 87:205-213

Reynolds HT, Currie CR (2004) Pathogenicity of Escovopsis weberi: the parasite of the attine ant-microbe symbiosis directly consumes the ant-cultivated fungus. Mycologia 96:955-959

Ribeiro PL, Navas CA (2007) The leaf-cutting ant Atta Sexdens rubropilosa, FOREL, 1908 prefers drier chambers for garbage disposal. J Insect Behav 20:19-24

Roces F, Hölldobler B (1994) Leaf density and a trade-off between loadsize selection and recruitment behavior in the ant Atta cephalotes. Oecologia 97:1-8
Roces F, Kleineidam C (2000) Humidity preference for fungus culturing by workers of the leaf-cutting ant Atta sexdens rubropilosa. Insect Soc 47:348-350

Specht A, Diehl-Fleig E, Silva ME (1994) Atratividade de iscas de Beauveria bassiana (Bals) Vuill. A Formiga do gênero Acromyrmex (hymenoptera: Formicidae). An Soc Entomol Bras 23:99-104

Silva O. (1997) Fertilizantes, corretivos e solos: o tripé das plantas. Campinas: Instituto Campineiro de Ensino Agrícola. p 55

Silva KS, Castellani MA, Forti LC, Moreira AA, Lemos OL, Carneiro RCS, Khouri CR, Ribeiro AL (2011) Arquitetura de ninhos de Acromyrmex (Moellerius) balzani (Formicidae: Myrmicini: Attini) em pastagem na região sudoeste da Bahia. Pesqui Apl Agrotec 1:117

Sudd JH (1982) Ants: foraging, nesting, brood behavior and polyethism. In: Hermann HR (ed) Social insect. Academic Press, New York, pp $107-155$

Van Gils HAJA, Vanderwoude C (2012) Leafcutter ant (Atta sexdens) (Hymenoptera: Formicidae) nest distribution responds to canopy removal and changes in micro-climate in the southern Colombian Amazon. Fla Entomol 95:914-921

Verchot LV, Moutinho PR, Davidson EA (2003) Leaf-cutting ant (Atta sexdens) and nutrient cycling: deep soil inorganic nitrogen stocks, mineralization, and nitrification in Eastern Amazonia. Soil Biol Biochem 35:1219-1222

Verza SS, Forti LC, Lopes JFS, Hughes WOH (2007) Nest architecture of the leaf-cutting ant Acromyrmex rugosus rugosus. Insect Soc 54: 303-309

Waddington SJ, Hughes WOH (2010) Waste management in the leafcutting ant Acromyrmex echinatior: the role of worker size, age and plasticity. Behav Ecol Sociobiol 64:1219-1228 